\title{
Fogólábúak Somogy megyében (Mantoptera)
}

\author{
ÁBRAHÁM LEVENTE
}

ÁвRAнÁm L.: Mantis in Somogy county, Hungary (Mantoptera)

Abstract: From the Mantoptera only one species, Mantis religiosa can be found in Somogy county. It is widespread and protected by laws in Hungary. It prefers dry habitats. The species is illustrated with a colour picture.

\section{Bevezetés}

A fogólábúak elsôsorban a trópusokon és a szubtrópusi területen élố rovarok. Európában a mediterrán területeket kivéve csak egy faj, a közönséges imádkozó sáska vagy ájtatos manó fordul elő. Somogy megyében ez gyakori faj, különösen Belsố-Somogy száraz homokos vidékein él népesebb populációban, míg a jórészt erdôvel borított Zselicben csak gyér számban található. Ragadozó életmódja és sajátos párzási rítusa miatt közismert rovarfaj. Hazánkban a fajt a természetvédelmi törvények védik. Mivel csupán egyetlen közismert faj él hazánkban, így lelőhelyi adataival nagyon kevés helyen találkozhatunk a rovartani szakirodalomban. Somogy megye területéról is csak ismeretterjesztő közleményból ismert az elófordulása (ÄвRAHÁm 1993).

\section{Somogy megyében előforduló faj}

\section{Mantidae}

Mantis religiosa (Linnaeus, 1758)

\section{Irodalom}

ÁвRAнÁм, L. 1993: Védett állatok Somogyban (gerinctelenek) - Múzeumi Tájékoztató 4: 29-35.

ISSN 1587-1908 (Print); ISSN 2062-9990 (Online) 


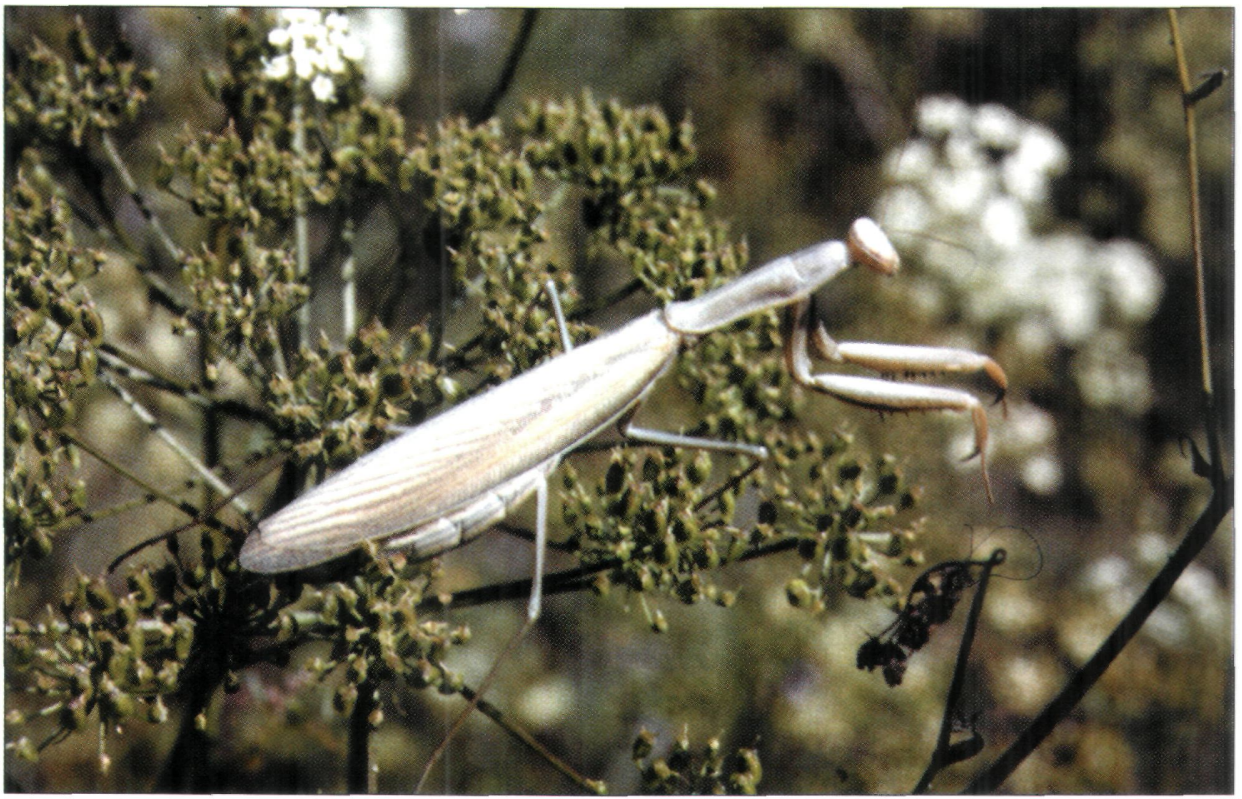

1. ábra: Az imádkozó sáska (Mantis religiosa) barna válzozata Belsô - Somogy homokvidékére jellemzó

\title{
Mantis in Somogy county, Hungary (Mantoptera)
}

\author{
LEVENTE ÁBRAHÁM
}

From the Mantoptera, only one species, Mantis religiosa (Linnaeus, 1758) occurs in the insect fauna of Somogy county, southwest Hungary. It is a protected species in Hungary.

Author's address:

Dr. Levente ÁBRAHÁM

Natural History Department

Somogy County Museum

H-7400 Kaposvár

Fö utca 10. P.o. Box 70.

HUNGARY 